Campbell2, working. in Gambia, who was able to confirm the difference in maxillary counts in females emerging from different breeding sites.

These conclusions are of considerable epidemiological and practical importance; but up to now it seems that critical attention has not been paid to the possibility that some of this morphological variation might be due to environmentel influences. To explore this possibility the following experiment was carried out.

Individual egg batches were obtained from wildcaught $A$. gambrae from Muheza in Tanganyika. Each batch was divided into two parts, which were reared separately, with the object of finding a combination of breeding conditions that might have a maximum effect on the maxillæ. One part was reared at a thermostatically controlled temperature of $32 \cdot 2^{\circ} \mathrm{C}$., the other at room temperature, which fluctuated around a mean of $21 \cdot 1^{\circ}$. As it was found that overcrowding influenced both the maxillary counts and wing-length, an average of 100-150 eggs was put into the hot bowls, and, with the exception of the first experiment, 300-450 into the cool bowls. Thus 400-600 eggs were used in each experiment, the number of eggs taken from each batch depending on the number of batches available. Eggs were trans. ferred to the appropriate bowls (12 in. $\times 10$ in.) some 12-36 hr. after deposition; pupæ were reared in separate containers but at the same temperature as their respective larvæ. All larvæ were fed on a suspension of a commercial preparation of yeast ('Perolin'). Little difficulty was encountered with feeding, although there was a considerable mortality among the later instar larvæ in the crowded bowls.

The results of six experiments on these two genetically identical groups, shown in Table 1 , gave striking evidence of the wide variation in maxillary index that could be induced by simple alteration of the larval environment. It appeared also that growth of the maxillæ was not obviously related to linear growth as measured by wing-length (parents, $2.9 \pm 0.06 \mathrm{~mm}$.; hot bowls, $2.72 \pm 0.06 \mathrm{~mm}$.; cool bowls, $3 \cdot 12 \pm 0.06 \mathrm{~mm}$.).

Table 1. MaXinhary INDEX OF A. gambiae REAREd UNDER DIFHERENT LABORATORY CONDITIONS. SIX EXPHRIMENTS

\begin{tabular}{|c|c|c|c|c|c|}
\hline \multicolumn{2}{|c|}{$\begin{array}{c}\text { Parents } \\
\text { wild-caught }\end{array}$} & \multicolumn{4}{|c|}{ hot, uncrowded $\left.\right|_{\text {bowls }} ^{\text {Progeny }}$ cool, crowded } \\
\hline No. & Max. index & No. & Max. index & No. & Max. index \\
\hline $\begin{array}{r}3 \\
14 \\
16 \\
20 \\
5 \\
5\end{array}$ & $\begin{array}{l}14 \cdot 8 \\
14 \cdot 2 \\
14 \cdot 3 \\
14 \cdot 5 \\
15 \cdot 5 \\
14 \cdot 6\end{array}$ & $\begin{array}{l}30 \\
22 \\
50 \\
35 \\
52 \\
37\end{array}$ & $\begin{array}{l}15 \cdot 7 \\
16 \\
15 \cdot 4 \\
16 \cdot 1 \\
16 \\
15 \cdot 9\end{array}$ & $\begin{array}{l}26 \\
59 \\
39 \\
21 \\
35 \\
32\end{array}$ & $\begin{array}{l}15 \cdot 2 \\
14 \cdot 1 \\
13 \cdot 8 \\
14 \cdot 6 \\
14 \cdot 4 \\
14\end{array}$ \\
\hline 63 & $14 ; 5 \pm 0 \cdot 6$ & 226 & $15 \cdot 8 \pm 0 \cdot 3$ & 212 & $14 \cdot 3 \pm 0 \cdot 3$ \\
\hline
\end{tabular}

This work makes it clear that, unless adults are reared under standard conditions, no valid comparisons can be made of the maxillary indices of populations cerived from different locelities or breeding sites. On these grounds, the conclusion of Holstein and Campbell, that the differences between the two populations of $A$. gambiae that they studied were genetically determined, cannot be accepted as it stands; nor can the possibility be ruled out that much of this variation was phenotypical.

While differences of a geographical nature may, and probably do, exist, it must be concluded that there is no convincing evidence available at present that points to the co-existence in the same region of biological races of this species.

East African Malaria Unit,

M. T. GILLIES

Tanganyika Malaria Unit,

G. T. SHUTE

Amani, Tanganyika.

Nov. 11.

${ }^{1}$ Holstein, M. H., Bull. méd. Afr. occid. franc., No. spéc., 155 (1949).

${ }^{2}$ Campbell, R. W. H., Bull. Ent. Res., 42, 647 (1951).

\section{Failure to Publish Scientific Results}

I wISH to direct attention to the large amount of scientific work carried out at the public expense but only reported in brief summary terms or published after long delay. This may be due in part to habits acquired in war-time, when the scientist was too busy to prepare papers for publication and the journals so restricted that they could not accept them. It is due also to the dangerous custom of writing a number of progress reports which are circulated within groups of Government committees in stencil : the authors frequently do not face the labour of preparing a paper of the type which a conscientious editor would accept.

It seems that an example is furnished by some of the work carried out under the Colonial Research Council*. Under that Council is a committee dealing with insecticides which met first in January 1947. Since the report for 1948-49, that Committee has referred each year to experiments being done with insecticidal sprays from the air in East Africa. It is evident from the page or so published that the investigation is well staffed (indeed in the last year the staff consisted of " 4 entomologists, a physicist, a chemist, a senior executive officer and 9 European assistants"); it also appears to be well planned: one notes that there is a careful estimation both of the insecticide that reaches the ground and of the insect populations which are the target. The group of workers carrying this out appear to have published no scientific papers until the end of $1953^{1,2}$. These papers apparently deal with experiments carried out so long ago as March 1948.

It seems probable that the work done by this group in East Africa is more full and careful than that performed by any other country; but if one wishes to know about insect destruction by aerial spray, one must use the other people's work because it is available.

This British work on insecticides is lavishly financed and has received $7 \cdot 5$ per cent of the $£ 12,000,000$ allocated to the Colonial Research Council up to 1953 , namely, $£ 900,000$. As most of the work carried out by the Insecticide Committee appears not to be very expensive, we conclude that the air spraying has cost about three-quarters of a million pounds. It is difficult to see why work should be done and paid for, if it is not made available or if it is to be published after it is out of date.

London School of Hygiene

P. A. Buxton

and Tropical Medicine, Keppel Street,

London, W.C.1. Jan. 29.

* See p. 374 of this issue of Nature.

${ }^{1}$ Hocking and Yeo, Bull. Ent. Res., 44, 589 (1953).

"Hocking, Parr, Yeo and Robins, Bull. Ent. Res., 44, 601 (1953). 